\title{
The Effects of Oil Price Shocks and Exchange Rate Volatility on Inflation: Evidence from Malaysia
}

\author{
Mohd Shahidan Shaari ${ }^{1}$, Nor Ermawati Hussain ${ }^{2}$ \& Hussin Abdullah ${ }^{2}$ \\ ${ }^{1}$ School of Business Innovation and Technopreneurship, University Malaysia Perlis, Malaysia \\ ${ }^{2}$ School of Economics, Finance and Banking, College of Business, University Utara Malaysia, Malaysia \\ Correspondence: Mohd Shahidan Shaari, School of Business Innovation and Technopreneurship, University \\ Malaysia Perlis, Malaysia. E-mail: shahidanshaari@unimap.edu.my
}

Received: June 20, 2012

Accepted: July 18, $2012 \quad$ Online Published: August 8, 2012

doi:10.5539/ibr.v5n9p106

URL: http://dx.doi.org/10.5539/ibr.v5n9p106

\begin{abstract}
The objective of this paper is to examine the effects of oil price shock on inflation in Malaysia, using monthly data from 2005 to 2011. VAR-VECM and Granger Causality model were employed to analyze the data. The cointegration between all variables are existence also at 5\% significant level in the long run. But in the short run, only oil crude price affected the inflation. For granger causality test, we found that the inflation does not granger cause to the exchange rate but it does granger cause to the oil price. The oil price does granger cause to the inflation but it does not granger cause to the exchange rate. The exchange rate does not granger cause to both of the variables (Inflation and Oil Price). So, the oil crude price can give an effect on inflation. If the rate of oil crude price changes, the inflation also changes. This finding will contribute to Malaysian government in making policy to control the petrol price to avoid from the inflation.
\end{abstract}

Keywords: oil price shock, real exchange rate, inflation, VAR-VECM, granger causality

\section{Introduction}

Theoritically, an increase in petrol price causes the cost of production to increase. As a result, aggregate supply shifts to the left, impying that productions fall. Most of the studies found out that a hike in petrol price caused inflation, decrease in output, higher unemployment rate and others. The world petrol price has always been decreasing from 1990 to 2007. In 2008, the world petrol price reached almost 100\% change. This change raised many issues accross the world especially in developing countries such as China and India. These two countries were largely affected because they were the largest oil consumption countries in the world. The world petrol price started to decrease after being at the highest level of 114.6US dollar. When the world experienced a decrease in petrol price, it actually eased the burden of many people especially poor people. Petrol is the main commodity to generate our economy.

In India, people suffered from the increase in petrol price by Rs 5 a litre. This was the steepest increase since December 2008. The India's goverment decontrolled the petrol price in Jun 2010. As a result, the goods price increased by almost Rs 7. The petrol price was at Rs 63.37 on May 15, 2011 which was Rs 15.44 higher than the petrol price on April 1, 2010. India always faced the increase in petrol price from 2010 to 2011. The hike in perol price caused the inflation by $8.98 \%$ in India. This inflationary pressure made the gross domestic product below the target of $9 \%$.

In 2008, the Chinese Goverment increased the petrol price around $18 \%$ on June 19, 2008. This change has caused the inflation. Hence, many people suffered from the lower purchasing power and propelled them to express their protest and execute demonstration. Some of the rifineries were shut down due to the sharp increase in petrol price. In May, 2011, China again increased the price of petrol by 350 Yuan in May. China was the second largest fuel consumption country after India. China resorted to increase the petrol price by $4.6 \%$ as the world petrol price reached above US\$100 per barrel. The last increase in petrol price was on December 22, 2010 after the incease in October and April 2010, that was the third time, China has faced increases in petrol price in 2010. In 2011, China had to suffer from $4.9 \%$ inflation and triggered off the indignation among the citizen. Therefore, China took action to control rising costs of food and other items. The rising petrol price in China was a very sensitive issue. 
Figure 1 shows the trend of oil price In Malaysia from 2005 to 2012. The figure depicts the fluctuation of oil price happened in that period, it was recorded a drastic increase from RM1.92 to RM2.70 in 2008. Started from 1st November 2008, the Malaysian Government decontrolled the petrol price due to a huge burden of the cost to the goverment. We could see the impact of the huge increase in petrol price on inflation in every goods and services such as food and transportation. A National Bank of Malaysia govenor, Tan Sri Dr Zeti Akhtar Aziz said that 5\% inflation was projected to happen due to the sharp rise in the petrol price. On August 22, 2008, the government announced a decrease in fuel price by 8 to 20\%, started 23 August 2008. On September 24, 2008, the government alleviated a burden of Malaysian by decreasing $10 \%$ in accordance with a sharp decline in global market. Started from October 15 , the price was adjusted again to a lower level by $10 \%$ and $20 \%$ change. Substantially, on 1 November, the price kept decreasing by $15 \%$ and even on November 18 and December 2008. In 2011, the fluctuation of oil price kept occuring where the increase happened for four times. The increase is very obvious from January to Mei. Until now the issue of oil price never seems to end.

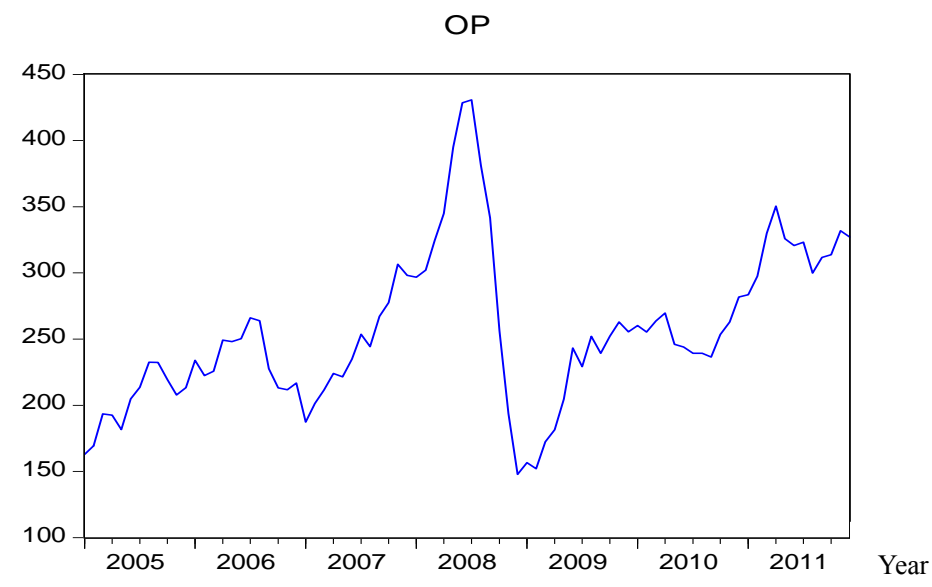

Figure 1. The Oil Price (OP) in Malaysia from January 2005 to 2011

The exchange rate is one of the determinants of the economy for countries. It caused unconfidence among investors. The Malaysian goverment fixed the exchange rate in 1998. The exchange rate was not longer determined by the demand and supply. In that time, the currency was at RM3.80/US $\$ 1$. This action was due to the financial crisis hit in Malaysia in that year. The fluctuation of exchange rate will have a detrimental effect on the inflation. If domestic currency for example Ringgit Malaysia depreciates, the imported goods price will be automatically increased. Local consumers need to pay higher for the imported products. Figure 2 shows the Malaysian exchange rate (RM per US \$1) from 2005 to 2011. Malaysia faced fluctuation in exchange rate in that period. The currency of exchange rate in January 2005 was around RM3.80 and dropped to RM3.16 in April 2008. After that, the exchange rate increased to RM3.67 in March 2009 and decreased again to RM3.09 in October 2010. In August 2011, the exchange rate was below RM3.00 and the exchange rate rose to RM3.15 in December 2011. This paper is to examine the effect of oil price and exchange rate on inflation in Malaysai from January 2005 to December 2011.

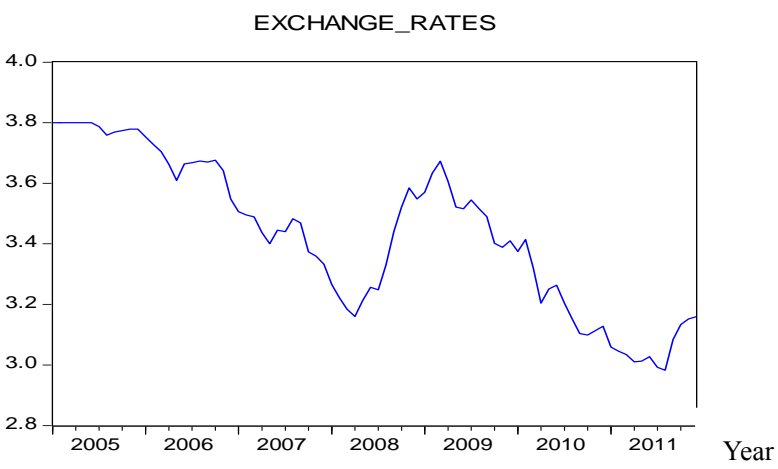

Figure 2. The Exchange Rates in Malaysia from January 2005 to 2011 


\section{Literature Review}

The price of goods and services are sensitive to oil price shock. Inflation can be caused by a higher petrol price. Oil price seems to be inextricably connected to inflation. Arinze (2011) used simple regression analysis and found out that whenever petrol price increases, it caused inflation rate to increase as well. It means that there was positive relationship between inflation and oil price. The impact of the change in petrol price on inflation can be seen through the increase in consumer price index. The higher petrol price drives consumer price index to increase. As a result inflation occurs. Olivier and Jordi (2007) found out the contribution of oil shocks to CPI inflation has increased in the recent period. This is consistent with a relatively stable CPI, with oil price changes were passed through to the energy component of the CPI. Based on their estimates, it was as much as sixty percent of the fluctuations in overall CPI inflation (Mun, 2008).

LeBlanc and Chin (2004) estimated the effects of oil price changes on inflation for the United States, United Kingdom, France, Germany, and Japan by employing Augmented Philips Curve Parameter Estimates and Associated Statistics. It was found that current oil price increases gave a modest effect on inflation in the U.S, Japan, and Europe. Oil price increases of as much as 10 percentage increase in oil price caused the inflation to increase around 0.1-0.8 percent in the U.S. and the E.U. In Europe, the oil price had a larger effect on inflation compared to the United States.

Cologni and Manera (2005) stated that in most of G-7 countries, oil price had an effect on inflation and output growth. The higher oil price caused the higher inflation and the lower output growth. Most of the countries reacted to the problems by increasing interest rate to overcome the inflation. Ito (2008) examined the impact of oil price and monetary shocks on the Rusian economy. His finding showed that a $1 \%$ increase in oil prices caused real GDP to increase by $0.25 \%$ and inflation by $0.36 \%$. Besides that the interest rate also influenced the real GDP growth and inflation.

Global oil price has played a main role to determine inflation in one country. Chou and Tseng (2011) examined the short-term and long-term pass-through effects of oil prices on inflation in Taiwan from 1982M1-2010M12 by applying ARDL model with the augmented Philips curve. The result showed that global oil prices had a significant effect on inflation in long term but in short term the result proved that the effect is not significant.

Besides, the oil price also can affect food inflation. Ali and Ramzam, et al (2012) examines the effect of high speed oil prices on food sector prices in Pakistan by using simple regression. They found out that there was a positive effect of oil price on food inflation such as wheat price, maize price, rice price, cooking oil price and chicken price.

However, there was a past study which indicated that an increase in oil price did not really affect inflation. Philip and Akintoye (2006) used VAR method to analyze the data and they ascertained that the oil price shocks did not give substantial effects on output and inflation rate in Nigeria from 1970 to 2003. But the oil price shock had a substantial effect on exchange rate.

The factor of exchange rate also will also give an effect on inflation. Nguyen and Seiichi (2007) said that in Vietnam before 1999, there are dual casuality in the relationship between the real exchange rate and price level. Not only in Vietnam, the strong relationship between inflation and real exchange rates exist in other ASEAN countries, for example Malaysia, Singapore, Thailand and China. Noer, Arie, et all (2010) the nominal exchange rate depreciation gave an impact on the inflation and the inflation prompted nominal exchange rate depreciation. They found out the same result on the relationship between real exchange rates and inflation.

\section{Methodology}

This study employs an empirical analysis and only focusseson three chosen variables. The variables that we use are the world crude oil price index (in Malaysian Ringgit, RM), Consumer Price Index, CPI (based index value of 100 in year 2005) and exchange rate (RM per \$1 US Dollar). Time series data from January 2005 (2005:1) to November 2011 (2011:11) are used for all variables in Malaysian country. The following equation 1 is the estimated equation that will be used in this study.

$$
C P I_{t}=\beta_{0}+\beta_{1} O P_{t}+\beta_{2} E X_{t}+\varepsilon_{t}
$$

Where $C P I_{t}$ is consumer price index for period t. $O P_{t}$ is Crude Oil Price for period t, and $E X$ is exchange rates for period t. To get the best result, the equation must be in log for all variables. This is to see the percentage of change in dependent variables when the independent variables change around 1 percent.

$$
\ln C P I_{t}=\beta_{0}+\beta_{l} \ln O P_{t}+\beta_{2} \ln E X_{t}+\varepsilon_{t}
$$


The tests that will be used in this study are unit root test, granger causality, co-integration test and also Vector Error Correction Model (VECM). Unit root test is applied to see the stationary of the series at the level and first difference test by using Augmented Dickey Fuller (ADF) and also Akaike Information Criteria (AIC). If this stationary test has a significant, it means that the variable series is stationary and does not has a unit root test, so the null hypothesis will be rejected but alternative hypothesis will be accepted (Trung \& Vinh, 2011). But if the stationary test is not significant, it means that the variable series is non-stationary and has a unit root test (so, null hypothesis will be accepted). The hypothesis in this test is:

$\mathrm{H}_{0}: \delta=0$ (unit root test / not stationary)

$\mathrm{H}_{1}: \delta \neq 0$ (no unit root test / stationary)

If the value of t-statistic is greater than ADF critical value, the null hypothesis is not rejected (unit root test exists) but if the t-statistic is less than ADF critical value, the unit root test does not exists (so, the null hypothesis is rejected). Firstly, the unit root test is done in level (unit root test in level with constant and unit root test in level with constant and trend) and after that, the unit root test is carried out in first difference (unit root test in first difference with constant and unit root test in first difference with constant and trend). The following equation 3, 4 and 5 are the equation in level without constant and trend, in level with constant only and with constant and trend.

Without constant and trend

$$
\Delta Y t=\delta Y t-1+U t
$$

With constant only

$$
\Delta Y t=\alpha+\delta Y t-1+U t
$$

With constant and trend

$$
\Delta Y t=\alpha+\beta T+\delta Y t-1+U t
$$

The co-integration test is also used in this study to examine the long run relationship between all variables (crude oil price, CPI, and exchange rate). In this co-integration test, two approaches will be used. The hypothesis for this study is:

\section{$\mathrm{H} 0: \delta=0$ (not stationary for $\widehat{\mu_{t}}$ or not co-integration if $t_{\delta}>\tau$ )}

H1: $\delta<0$ (stationary for $\widehat{\mu_{t}}$ or have co-integration ift $t_{\delta}<\tau$ )

where $\widehat{\mu_{t}}$ is an error term and $\tau$ is a critical t-statistic in this model. The Engle-Granger procedure is used to examine the stationary for variablesin level of the residual term. But, the Engle-Granger does not settle the problem if there are many variables co-integrated whereas we assumed that only one vector has co-integration. So, Johansen test will be used in this study to solve the problem by using the Vector Autoregression (VAR) system for the variables. The Vector Error Correction Model (VECM) includes the error correction model which is to examine dynamic behavior of the model. The VECM explains the examined model is adjusting in each time period towards its long run equilibrium. It shows that the disequilibrium will converge to long run equilibrium state. The VECM is also to see the relationship between the variables in the short run. The following equation 6 shows the VAR equation.

$$
Y_{t}=\sum_{j=1}^{k} A_{j} Y_{t-j}+\mu_{t}
$$

After doing the co-integration test, the granger-causality test is also applied in this study to determine the causality relationship between the variables. The causality test is to see a reaction between the variables. For example, if variable $\mathrm{X}$ is granger cause to $\mathrm{Y}$ and $\mathrm{Y}$ is also granger cause to $\mathrm{X}$, it means that the value after $\mathrm{X}$ can help to expected value for the next period of $Y$ and also the value after $Y$ can help to expected value for the next period of $\mathrm{X}$ (Sorensen,2005). The following equation 7 and 8 are the formula for granger causality regression test for two-way variable and $\mathrm{Y}$.

\section{Findings Result}

$$
\begin{aligned}
& Y_{t}=\sum_{i=1}^{p} \sigma_{i} Y_{t-1}+\sum_{i=1}^{q} \beta_{j} X_{t-j}+\mu_{1 t} \\
& X_{t}=\sum_{i=1}^{p} \gamma_{i} Y_{t-1}+\sum_{i-1}^{q} \delta_{j} X_{t-j}+\mu_{2 t}
\end{aligned}
$$

Table 1 shows the result the Augmented Dickey Fuller (ADF) and Phillips Perron (PP) test of unit root test. The result below shows that all variables (oil crude price, CPI and exchange rate) are non-stationary in level with constant and constant with trend. But in first difference test, the result for all variables shows that they are 
significant at five percent. It means that all variables are stationary. Thus, the null hypothesis is rejected and the alternative hypothesis is accepted.

Table 1. Unit Root Test

\begin{tabular}{|c|c|c|c|c|c|c|c|c|}
\hline & \multicolumn{4}{|c|}{ Augmented Dickey Fuller (ADF) } & \multicolumn{4}{|c|}{ Phillips Perron (PP) } \\
\hline & \multicolumn{2}{|l|}{ Intercept } & \multicolumn{2}{|c|}{ Intercept + Trend } & \multicolumn{2}{|c|}{ Intercept } & \multicolumn{2}{|c|}{ Intercept + Trend } \\
\hline & Level & $\begin{array}{l}\text { First } \\
\text { Difference }\end{array}$ & Level & $\begin{array}{l}\text { First } \\
\text { Difference }\end{array}$ & Level & $\begin{array}{l}\text { First } \\
\text { Difference }\end{array}$ & Level & $\begin{array}{l}\text { First } \\
\text { Difference }\end{array}$ \\
\hline Oil Price & $\begin{array}{l}-1.8489 \\
(0.3547)\end{array}$ & $\begin{array}{l}-5.54^{* *} \\
(0.0000)\end{array}$ & $\begin{array}{l}-1.9527 \\
(0.6179)\end{array}$ & $\begin{array}{l}-5.5066^{* *} \\
(0.0001)\end{array}$ & $\begin{array}{l}-2.5542 \\
(0.1067)\end{array}$ & $\begin{array}{l}-5.5881^{* *} \\
(0.0000)\end{array}$ & $\begin{array}{l}-2.7709 \\
(0.2122)\end{array}$ & $\begin{array}{l}-5.5561^{* *} \\
(0.0001)\end{array}$ \\
\hline CPI & $\begin{array}{l}-0.7364 \\
(0.8310)\end{array}$ & $\begin{array}{l}-5.8636^{* *} \\
(0.0000)\end{array}$ & $\begin{array}{l}-1.9547 \\
(0.6169)\end{array}$ & $\begin{array}{l}-5.8344^{* *} \\
(0.0000)\end{array}$ & $\begin{array}{l}-0.7964 \\
(0.8147)\end{array}$ & $\begin{array}{l}-5.8255^{* *} \\
(0.0000)\end{array}$ & $\begin{array}{l}-2.5362 \\
(0.3104)\end{array}$ & $\begin{array}{l}-5.7950^{* *} \\
(0.0000)\end{array}$ \\
\hline $\begin{array}{l}\text { Exchange } \\
\text { Rate }\end{array}$ & $\begin{array}{l}-1.1209 \\
(0.7043)\end{array}$ & $\begin{array}{l}-6.2956^{* *} \\
(0.0000)\end{array}$ & $\begin{array}{l}-1.4918 \\
(0.8248)\end{array}$ & $\begin{array}{l}-6.2698^{* *} \\
(0.0000)\end{array}$ & $\begin{array}{l}-1.2542 \\
(0.6473)\end{array}$ & $\begin{array}{l}-6.3601^{* *} \\
(0.0000)\end{array}$ & $\begin{array}{l}-1.9076 \\
(0.6417)\end{array}$ & $\begin{array}{l}-6.3347^{* *} \\
(0.0000)\end{array}$ \\
\hline
\end{tabular}

Note: $^{* * *},{ }^{* *}$ and ${ }^{*}$ indicates the rejection of the null hypothesis of non-stationary at $1 \%, 5 \%$ and $10 \%$ significance level.

The main focus in this paper is to assess how inflation in the long run react to exchange rate and whether oil price exist or not. Thus, in order to see the co-integration or relationship among the variables, the co-integrating test is used in this study. Table 2 presents the result for co-integration test. The result shows that both maximum-Eigen statistic and trace statistic are presence in Malaysian economy at 5\% level among 3 variables. It means that, the long-run equilibrium relationship between the variables and oil crude price do exist. At null hypothesis, the trace statistic value is 34.6678 higher than the critical value (trace) 29.7971 at $5 \%$ significant level. This trace statistic result presents that this equation has the long run relationship between the variables at 5\% significant level. For Max-Eigen statistic, the result also shows the relationship between the variables in the long run at 5\% significant level as a result of the Max-Eigen statistic 25.0657 which is higher than critical value (Eigen) 21.1316 at 5\% significant level. Johansen procedure is also applied in this study to see the long run coefficients of model.

Table 2. Cointegration Test

\begin{tabular}{|c|c|c|c|c|}
\hline $\begin{array}{l}\text { Hypothesized } \\
\text { No. of CE(s) }\end{array}$ & Max-Eigen Statistic & Critical value (Eigen) at $5 \%$ & Trace Statistic & Critical value (Trace) at $5 \%$ \\
\hline $\mathrm{r}=0$ & $25.0657^{* *}$ & 21.1316 & $34.6678^{* *}$ & 29.7971 \\
\hline $\mathrm{r} \leq 1$ & 8.3498 & 14.2646 & 9.6021 & 15.4947 \\
\hline$r \leq 2$ & 1.2523 & 3.8415 & 1.2523 & 3.8415 \\
\hline
\end{tabular}

Note: ${ }^{*},{ }^{* *}$ and ${ }^{* * *}$ denote statistical significance at the $10 \%, 5 \%$ and $1 \%$ level, respectively.

Table 3 below presents the test for the short run vector correlation model (VECM). Optimal lag selection has been done to choose lag. The choice is based on Akaike Information Criterion. The parameter of the error correction in terms of the model is negative and significant at 5\% level. For the model when gross domestic product is dependent variable, the result shows that the inflation has an automatic adjustment mechanism and that responds to correction deviations from equilibrium in a balancing manner. The error correction coefficient confirms that inflation will converge towards its long run equilibrium after the change in the oil price and exchange rate. The result of the VECM test also shows that the change in dependent variable is affected by independent variables in the short run. Only crude oil price does affect the inflation but the exchange rate does not affect the inflation in Malaysia. This is because only oil crude price has statistical significance in Johansen procedure at significant level.

Table 3. Short Run Vector Correlation Model (VECM)

\begin{tabular}{llll}
\hline & coefficient & t-statistic & Prob. \\
\hline$\Delta \mathrm{EX}(-1)$ & -0.8587 & -0.6268 & 0.178 \\
$\Delta \mathrm{OP}(-1)$ & $0.0102^{* *}$ & 3.3256 & 0.0013 \\
$\Delta \mathrm{CPI}(1)$ & 0.1557 & 1.3593 & 0.5326 \\
$\mathrm{ECM}(-1)$ & $-0.0133^{* *}$ & -3.1201 & 0.0025 \\
\hline
\end{tabular}

Note: The lag length is selected using the Akaike Information Criteria (AIC). ${ }^{*},{ }^{* *}$ and ${ }^{* * *}$ denote statistical significance at the $10 \%, 5 \%$ and $1 \%$ level, respectively. 
The Granger Causality test is to determine whether the pair of time series data has a correlation or not (causal between 2 variables). The correlation for granger causality test only can be applied for all variables. If the F-statistic for is smaller than the F-critical, it means that no granger cause between both variables. Table 4 presents the Granger Causality/ block exogeneitywald tests among consumer price index (CPI) exchange rate (EX) and oil crude price (OP) volatility. For the correlation with CPI as dependent variable, the result for all is significant at 5\% level (only independent variable of oil crude price is granger cause to CPI). For the correlation with oil price as dependent variable, the result for all variables is also significant at $5 \%$ level (the independent variables of CPI is granger cause to oil crude price). While the correlation with exchange rate as dependent variable, the result for all variables is not significant (no independent variable is granger cause to exchange rate).

Table 4. Granger Causality/ Block Exogeneity Wald Tests

\begin{tabular}{|c|c|c|c|c|c|}
\hline \multirow[t]{2}{*}{ Dependent variable } & \multicolumn{4}{|c|}{ Short run causality (wald test) } & \multirow{2}{*}{$\begin{array}{l}\text { Long run causality } \\
\text { ECT }_{t-1}\end{array}$} \\
\hline & $\Delta \mathrm{CPI}$ & $\Delta \mathrm{OP}$ & $\Delta \mathbf{E X}$ & All & \\
\hline \multirow[t]{2}{*}{$\Delta \mathrm{CPI}$} & - & $14.2256^{* *}$ & 0.0207 & $16.0239^{* *}$ & $-0.01334^{* *}$ \\
\hline & & $(0.0002)$ & $(0.8856)$ & $(0.0003)$ & {$[-3.1201]$} \\
\hline \multirow[t]{2}{*}{$\Delta \mathbf{O P}$} & $5.7228^{* *}$ & - & 0.1279 & $5.7967^{*}$ & $0.4661^{* *}$ \\
\hline & $(0.0167)$ & & $(0.7206)$ & $(0.0551)$ & {$[3.1325]$} \\
\hline \multirow[t]{2}{*}{$\Delta \mathbf{E X}$} & 0.0503 & 1.7315 & - & 2.2345 & -0.0006 \\
\hline & $(0.8225)$ & $(0.1882)$ & & $(0.3272)$ & {$[-1.6629]$} \\
\hline
\end{tabular}

Note: The values in [] and () are t-statistic and p-value respectively. ${ }^{*},{ }^{* *}$ and ${ }^{* * *}$ denote statistical significance at the $10 \%, 5 \%$ and $1 \%$ level, respectively.

\section{Conclusion}

This paper is to find out the relationship and causality between inflation, oil crude price and exchange rate from January 2005 until December 2011. The Malaysia oil crude price normally has a fluctuation from January 2005 until December 2011. However, the oil crude price has achieved a higher price in June 2008 and dropped sharply during July 2008. But the inflation is increasing every month from January 2005 until December 2011. If we see the relationship between inflation and oil crude price, we agree with Yip, Lim and Asan Ali (2009) that when the oil price increased, the economic became slow but when the oil crude price decreased, it did not affect the economy since the inflation always increased progressively from month to month. The exchange rate also has a fluctuation from month to month starting from January 2005 to December 2011.

For stationary test, all variables (oil crude price, inflation and exchange rate) are stationary at 5 percent significant level. So, the null hypothesis is rejected. The co-integration among all variables do exist at 5 percent significant level in the long run. But in the short run, only oil crude price does affect the inflation. For granger causality test, we can conclude that the inflation does not granger cause to the exchange rate but it does granger cause to the oil price. The oil price does granger cause to the inflation but it does not granger cause to the exchange rate. The exchange rate does not granger cause to both of the variables (Inflation and Oil Price). So, the oil crude price can give an effect on inflation. If the rate of oil crude price changes, the inflation also changes.

This finding will contribute to Malaysian government in making policies to strictly control the petrol price. This is because the oil price shock caused inflation in Malaysia from 2005 to 2011. The inflation is not good for the country as it may burden poor people to subsist in high cost of living. Poverty line will escalate when inflation happens. It automatically intensifies poverty in Malaysia.

\section{References}

Achsan, N. A., Jayanthy, A., \& Abdullah, F. (2010). The Relationship between Inflation and Real Exchange Rate: Comparative Study between ASEAN+3, the EU and North America. European Journal of Economics, Finance and Administrative Sciences, 18, 1450-2275.

Ali, S. A., Ramzam, M., Razi, M., \& Bhatti, A. G. (2012). The Impact of Oil Prices on Food Inflation in Pakistan. Interdisciplinary Journal of Contemporary Research in Business, 3(11).

Aliyu, S. U. R (2009). Impact of Oil Price Shock and exchange Rate Volatilityon Economic Growth in Nigeria: An Empirical Investigation. Research Journal of International Studies, 11.

Blanchard, O. J., \& Gal, J. (2007). The Macroeconomic Effects of Oil Price Shocks: Why are the 2000s so different from the 1970s? http://web.mit.edu/ceepr/www/publications/workingpapers/2007-011.pdf 
Bolaji, B. O., \& Bolaji, G. A. (2010). Investigating the Effects of Increase in Oil Prices on Manufacturing Companies in Nigeria. The Pacific Journal of Science and Technology, 11(2), 387-390.

Celasun, O., Mihet, R., \& Ratnovski, L. (2012). Commodity Prices and Inflation Expectations in the United States. IMF Working Paper.

Cologni, A., \& Manera, M. (2005). Oil Prices, Inflation and Interest Rates in a Structural Cointegrated VAR Model for the G-7 Countries. Working Paper.

Farzenagan, R. M., \& Markwardt, G. (2007). The Effects of Oil Price Shock on the Iranian Econom. http://www.ecomod.org/files/papers/600.pdf

Hamsin, M. F. (2012). Fenomena Kenaikan Harga Minyak Mentah Dunia (15 Jun 2008). MindaMidani Online.

Ito, K. (2008). Oil Price and the Russian Economy: A VEC Model Approach. International Research Journal of Finance and Economics, (17), 68-74.

Jalil, N. A., Ghani, G. M., \& Duasa, J. (2009). Oil Prices and TheMalaysia Economy. International Review Business Research Papers, 5(4).

LeBlanc, M., \& Chin, M. D. (2004). Do High Oil Prices Presage Inflation? The Evidence from G-5 Countries. Economic Research Service.

Olomola, P. A., \& Adejumo, A. V. (2006). Oil Price Shock and Macroeconomic Activities in Nigeria. International Research Journal of Finance and Economics, (13).

Rebeca, J. R., \& Marcelo, S. (2004). Oil Price Shocks and Real GDP Growth: Empirical Evidence For Some OECD Countries. Working Paper Series. European CentralBank, 362.

Rohim, S. N. (2010). Ringgit Tertinggi 2 Tahun. LaporanEkonomi. Utusan Malaysia.

Sorensen, B. E. (2005). Granger Causality, Economics 7395.

Trung, V. T., \& Vinh, N. T. T. (2011). The Impact of Oil Prices, Real Effective Exchange Rate and Inflation on Economic activity: Novel Evidence For Vietnam. Discussion Paper Series. RIEB Kobe University.

Vinh, N. T. T., \& Fujita, T. (2007). The impact of Real Exchange Rate on Output and Inflation in Vietnam: A VAR approach. Discussion paper, No 0625.

Yin, Y. P., Eam, L. M., \& Hasan, A. A. G. (2009). The Impacts of Oil Shockson Malaysia's GDP Growth. Proceeding of the $5^{\text {th }}$ Asian Mathematical Conferences. 